\title{
Study on Block-Chain Implementation in Zakat Management (Case Study in Indonesia)
}

\author{
Bedjo Santoso ${ }^{1}$, Farikha Amilahaq ${ }^{2}$, Suraya Ahmad ${ }^{3}$, Noor Emilina Mohd Nasir ${ }^{4}$ \\ Universitas Islam Sultan Agung, Semarang, Indonesia ${ }^{1,2}$ \\ Universiti Technology of Mara, Dungun, Malaysia ${ }^{3,4}$ \\ \{bedjo.s@unissula.ac.id ${ }^{1}$,farikha@unissula.ac.id², suray4993@uitm.edu.my³, \\ nooremilina@uitm.edu.my ${ }^{4}$ \}
}

\begin{abstract}
Studies on the role of ICT in Zakat management have been carried out with the conclusion that the use of ICT can increase efficiency, convenience, and practicality in paying Zakat. However, the problems faced by Zakat institutions are: Trust, Credibility, Accountability, and Transparency. To deal with these issues is by using Block-chain technology. Thus, it is necessary to conduct a study in more detail of block-chain implementation in Zakat management. This research is a descriptive research involving 200 respondents as the sample throughout Indonesia. The sample includes Academicians, Islamic Finance Activists, Zakat Payer, and Scholars. The Sampling method used is area, stratified, purposive sampling. The result shows that the use of ICT can increase people awareness to pay Zakat. Secondly, the use of block-chain technology will increase the credibility value of institutions. Last but not least, the transparency will encourage people's belief and trust to the Zakat institution. Therefore, to design appropriate model Block-Chain is needed to facilitate good relationship among Zakat stakeholders. In term of TAM (Technology Acceptance Model) the use of Block-Chain in Zakat management will facilitate in three ways, namely; Perceived of Usefulness Perception, Increasing Performance and Perceived on Easiness of Use. The result also revealed that credibility is the most significant factor, and then followed by accountability, transparency, and trust.
\end{abstract}

Keywords: Zakat Management, ICT, Block-Chain, Zakat Institution

\section{Introduction}

One of the important concepts in asset management in Islam is the management of socioreligious funds and Zakat is a manifestation thing in this concept. However Zakat in Indonesia still poor, although Indonesia is a large Muslim country by more than 250 million population. It is therefore strengthening the Zakat management to realizing welfare state through increasing the power of people economic is big issue to be developed [12]. As in the history of Islam has approved that of Zakat has a major contribution in advancing Islamic civilization [20]. 
The general public more understands the distribution of Zakat limit to be given to those who are entitled, such as to the faqir, miskin, gharimin, mualaf, ibnu sabil, fisabilillah, riqab, and amil Zakat. Basically, the distribution of Zakat can be managed more optimally for the purpose of empowering the poor who are included in the 8 asnaf. In other words, Zakat is not only for meeting the consumptive needs of mustahiq [20].

Democratic freedom in the management of Zakat funds is shown by the number of amil Zakat institutions established by the community, while still being supervised by the National Amil Zakat Agency from the government. Authorization of Zakat management from Zakat collection to distribution of Zakat funds held by each institution makes reporting of Zakat management to stakeholders is very important. Stakeholders in this case are all people, both those who pay their Zakat through institutions, as well as government agencies as regulators and the legislative body (supervisors) for the implementation of Zakat management in Indonesia.

Several previous studies show the importance of professionalism of Zakat institutions in an effort to increase the tendency of people for paying Zakat through Zakat institutions. However, some people still worry the trust, credibility, transparency, and accountability of the Zakat institutions. Based on the study many Zakat institution neglecting this issues, whereas this items are considered as important point for the society, and it can reflect the people mindset in the community to increase the trust to Zakat institutions [13].

Block-Chain is new technology that has some feature deal with that issues, as block chain is open ledger account which is every member in the group can monitor any transactions change in the group. Besides that, based on block chain technology people can be able to make any transaction each other easily and very fast. Hence, it hope that this technology can settle the problem of trust, credibility, accountability, and transparency. The most important matter is how to increase public trust, credibility, transparency, and accountability to Zakat institutions, the propose one way is to adopt certain technology that can facilitate more good government of Zakat management [23]. Based on the above background, it is interesting to explore, investigate in more detail and to design appropriate model of Zakat fund management by utilizing an integrated information system technology (Block-Chain).

\section{Literature Review}

This part we will discuss the potential of Zakat, Zakat Management in Indonesia, Zakat Management based on Trust, Transparency, Credibility, and Accountability, Community Response to Information Technology-Based on Zakat Services, Block chain for Worldwide Zakat Management. Besides that, we also discuss Block chain in Indonesia, and Block-Chain Technology for Digital Zakat Management.

\subsection{Potential of Zakat}

The potential for cash Zakat that can be collected from the 200 million Muslim population is around IDR 300 trillion per year [12],[20]. However, the collection rate has only reached 2 percent of this potential, namely Rp. 3.7 trillion per year. Basically, this gap begins with a large gap between education about worship for Muslim children [21].

Muslims in Indonesia are familiar with the word Zakat. However, this familiarity does not make them really understand about Zakat. From childhood, children will be taught to perform 
prayers correctly from movements to prayer readings. However, education about Zakat is less of a concern, both in schools such as TPA, TPQ, and education by parents [21]. The mindset that Muslims have an orientation to become people who are able to give Zakat has not been instilled since childhood, so that the awareness to spend part of their assets has not become a priority for the Muslim community today.

On the other hand, the large potential of Zakat in Indonesia is dominated by contemporary types of Zakat compared to the compulsory Zakat yield categories that have been classified by classical scholars. However, it needs to be understood that contemporary ijtihad regarding Zakat that has emerged is still based on classical works and existing texts, not ijtihad without foundation [17][21]. Therefore, modernization in the field of muamalah is permitted by Islamic law, as long as it does not contradict the principles and Islamic law itself.

Moreover, it needs to be realized that human life and needs are always evolving and changing, so Islamic law in the field of muamalah, generally only regulates and establishes the basic principles of law in general. Meanwhile, the details are left to Muslims, wherever they are. This is in accordance with the principle of muamalah, namely "the law of origin stipulates that the conditions in muamalah are Halal unless there are arguments against it" [17mufrai].

In this modern era, there are many objects that are managed to obtain high economic value. Humans are not only able to exploit their external potential but modern humans can also exploit their existing potential to be developed and extracted and then take advantage of their expertise such as doctors, lawyers, lecturers and so on. Therefore, some contemporary categories of Zakat include Zakat on honey and animal production, Zakat on investment in factories, buildings and others, Zakat on profession, and Zakat on stocks and bonds. Even Dr. Yusuf Qordhowi also added Zakat of marine products which includes amber pearls and others [17].

On the other hand, the large potential of Zakat in Indonesia is dominated by contemporary types of Zakat compared to the compulsory Zakat yield categories that have been classified by classical scholars. However, it needs to be understood that contemporary ijtihad-ijtihad regarding Zakat that has emerged is still based on classical works and existing texts, not ijtihad without foundation [17][21]. Therefore, modernization in the field of muamalah is permitted by Islamic law, as long as it does not contradict the principles and Islamic law itself.

Moreover, it needs to be realized that human life and needs are always evolving and changing, so Islamic law in the field of muamalah, generally only regulates and establishes the basic principles of law in general. Meanwhile, the details are left to Muslims, wherever they are. This is in accordance with the principle of muamalah, namely "the law of origin stipulates that the conditions in muamalah are halal unless there are arguments against it" [17].

\subsection{Zakat Management in Indonesia}

The essence of Zakat that is generally understood by the public is that Zakat will be afdol if it has been received by those who have the right. However, the use of Zakat funds in the hands of mustahiq is not considered, whether it is only used to meet consumptive needs or will the Zakat funds be used to improve their economic conditions so that they can convert mustahiq into muzakki (people who are able and obliged to give Zakat). Moreover, it is feared that the distribution of Zakat for consumptive use can make mustahiq off guard and not try to have a better economic condition, because every year they feel sure that someone will give them, and they also have the right to ask muzakki for their rights.

The concept of Zakat fiqh explains that the Zakat system seeks to bring together surplus Muslim parties (muzakki) with deficit Muslim parties (mustahiq). This is with the hope that 
there will be an equal distribution projection between Muslim surpluses and deficits or even turning the deficit (mustahiq) into a surplus (muzakki) [21]. This means that the management of Zakat can change poor Muslims to become capable, shackled people (Muallaf, Gharimin, Riqab, and Fi Sabilillah) to be free, and turn stupid people (Ibn Sabil) into smart people. Thus, it is necessary to have a productive and effective Zakat distribution pattern in order to convert mustahiq into muzakki. Namely, with professional management of Zakat funds by considering market needs (mustahiq). Thus the benefits of Zakat will be more optimal and not only to meet the consumptive needs of mustahiq.

The management of Zakat by Zakat institutions can also prevent the sporadic or poorly organized management of Zakat funds. Because sometimes poor areas are generally located in an area where there are not many muzakki [17]. So that the distribution of Zakat funds is not only to some mustahiq in the muzakki area, but also from mustahiq to mustahiq in other areas which often have not received much assistance.

Zakat is one of the characteristics of the Islamic economic system because Zakat is a form of implementation of the principle of justice in Islamic economics. M.A. Mannan [20] in his book entitled Islamic Economics Theory and Practice states that Zakat has six principles, namely:

a) The principle of religious belief, namely that muzakki (people who are obliged to pay Zakat) are a manifestation of their religious beliefs,

b) The principle of justice and equity, this principle explains the social purpose of Zakat, namely by dividing the wealth given by Allah to be fairer and more equitable to humans.

c) The principle of productivity, this principle emphasizes that Zakat must be paid because the property can be used productively by those who are entitled,

d) The principle of rational, which is very rational that the Zakat of the property that produces it must be issued (given to mustahiq),

e) The principle of freedom, namely those who are obliged to pay Zakat are not slaves (people who are freedom),

f) The principle of ethics and reasonableness, which means that Zakat is collected by means of stipulated rules, and cannot be collected arbitrarily.

In Indonesia, the establishment of Zakat management organizations has been regulated in Law Number 23 of 2011 concerning Zakat Management. Zakat management organizations, whatever their form and position, generally have two functions [24], namely:

Firstly: As a financial intermediary, Amil became an intermediary between muzakki and mustahiq. Muzakki pays his Zakat through amil Zakat which will then be distributed to mustahiq with various methods of distribution and management of Zakat funds to achieve optimal benefits of Zakat fund distribution. As a financial intermediary, amil is also required to apply professionalism and management that is transparent and trustworthy to increase trust.

Secondly: Empowerment. This function is the main function of the existence of amil Zakat, namely striving for the distribution of Zakat funds to be carried out fairly, on target, and achieving optimal benefits, so that it is hoped that it can turn into a new muzakki.

Nowadays, there are many Zakat institutions in every region in Indonesia so that the distribution of Zakat is increasingly being carried out by Zakat institutions. The socialization is carried out by understanding the importance of tithing, the obligation to give Zakat, and the introduction of the role of Zakat institutions [21]. Especially now that more and more people are aware of social issues and the importance of giving, this is evidenced by the number of social crowdfunding campaigns or programs to help people who are experiencing disasters such as natural disasters or serious illness which require a lot of money for treatment. Building 
a Zakat awareness network will also seek and facilitate the optimization of the collection and distribution of Zakat funds.

Institutions as well as Zakat have implemented various innovations related to Zakat collection and management strategies, namely from traditional and conventional methods to becoming more modern, innovative and expansive. Such as a cash Zakat collection strategy that is not only done offline such as visiting muzakki door to door, serving muzakki through service offices, or opening outlets or stands in crowded places, but also transacting Zakat can be done online such as through the transfer system from the application, mobile or net banking, collaborating with marketplaces such as Bukalapak.com, or creating online websites for crowdfunding social funds. The collection strategy can increase Zakat donations and bring Zakat institutions closer to the community. Especially the millennial generation who are more active on online social media, and are a generation that in the next few years will have entered adulthood with a more mature financial condition (muzakki candidates).

However, the online Zakat collection strategy has not been balanced with the accountability of managing Zakat funds and Zakat assets online. Thus, this study not only looks at the potential for cash Zakat collection as a source of productive Zakat management, but also develops Zakat management strategies in a more integrated manner, both in terms of collection and publication of reports on the management and distribution of Zakat funds.

\subsection{Zakat Management based on Trust, Transparency, Credibility and Accountability}

Zakat management by utilizing digital technology is not only for the strategy of collecting Zakat, but also for the transparency of the performance of Zakat institutions to stakeholders/society at large. This urgency is based on the imbalance between Zakat fund collection strategies that have been modern and are being intensified by Zakat institutions, and Zakat institutions' attention to improve their method of accountability. Based on previous studies, it strengthens the importance of a transparent form of Zakat management reporting.

Table 1. The Urgency of Developing a Comprehensive Zakat Management Model

\begin{tabular}{|c|c|c|}
\hline No & $\begin{array}{l}\text { Previous } \\
\text { Researchs }\end{array}$ & Conclusion \\
\hline 1 & {$[15]$} & Expansion of beneficiaries will indirectly increase public trust. \\
\hline 2 & [13] & Trust influences the intention of the community to pay Zakat through the Zakat board. \\
\hline 3 & [9] & The transparency of the Rumah Zakat Amil Institute can increase the loyalty of muzakki. \\
\hline 4 & [11] & The credibility of Zakat institutions influences people's behavior to pay Zakat. \\
\hline 5 & [18] & The importance of accountability and transparency to increase trust. \\
\hline 6 & {$[22]$} & $\begin{array}{l}\text { By increasing the quality of Zakat institutions such as transparency, outreach and } \\
\text { administration. So that the preference for paying Zakat in these institutions will increase. }\end{array}$ \\
\hline 7 & [18] & $\begin{array}{l}\text { Transparency, accountability, and advantage are important variables in Good Governance at } \\
\text { the Zakat Agency, because these three variables have a significant effect on satisfaction and } \\
\text { loyalty. }\end{array}$ \\
\hline 8 & [15] & $\begin{array}{l}\text { Transparency of financial reports, Zakat management, attitude of managers partially and } \\
\text { simultaneously has a significant effect on trust muzakki. }\end{array}$ \\
\hline 9 & {$[15]$} & $\begin{array}{l}\text { The factors that dominate the behavior of paying Zakat: religion (they feel it is better to give } \\
\text { Zakat directly to mustahiqs who are still relatives / close / around them), the second factor is } \\
\text { the location of Zakat institutions that are far away, services that are considered unsatisfactory, } \\
\text { the credibility of Zakat institutions (community lack of confidence that Zakat institutions have } \\
\text { distributed appropriately because they are considered not transparent), and their income levels. } \\
\text { In other words, people want Zakat institutions to be more professional, manageable, } \\
\text { transparent, and have satisfying services.. }\end{array}$ \\
\hline 10 & [19] & $\begin{array}{l}\text { Charity organizations must ensure procedural transparency and emphasize the collection, } \\
\text { distribution and use of Zakat methods to attract more donors / muzakki. }\end{array}$ \\
\hline 11 & {$[25]$} & There is an urgency for the existence of amil Zakat. \\
\hline
\end{tabular}




\begin{tabular}{|c|c|c|}
\hline No & $\begin{array}{l}\text { Previous } \\
\text { Researchs }\end{array}$ & Conclusion \\
\hline 12 & {$[23]$} & $\begin{array}{l}\text { Ideally, paying Zakat through the state or Zakat institutions, however, the credibility of these } \\
\text { institutions could be doubted (there is a crisis of trust), so that the tendency that occurs is to } \\
\text { pay Zakat directly to the beneficiaries. Therefore, it is very important to create trust in the } \\
\text { collection and distribution of Zakat from amil Zakat so that it will encourage more Muslims to } \\
\text { pay their Zakat and distribution of Zakat by amil Zakat allows to reach as many Zakat } \\
\text { recipients as possible. This system encourages the creation of screening organizations / } \\
\text { institutions by Muslim professional accountants and others who can help make Zakat } \\
\text { management transparent and trustworthy. The institution must provide accountability reporting } \\
\text { to the community so that the community is willing to cooperate with them. In other words, } \\
\text { trust in the management of Zakat and the recommended ways in which trust can be built in the } \\
\text { collection and distribution of Zakat is effective. }\end{array}$ \\
\hline 13 & [26] & $\begin{array}{l}\text { The main factor in making people pay Zakat is an understanding of Zakat by young people. } \\
\text { Second, there are facilities and services available to facilitate the transaction to pay Zakat. }\end{array}$ \\
\hline
\end{tabular}
Source : various sources

Earlier researchers realized that if Zakat institutions want to increase their collection, it must prove that they are quite trustworthy in managing Zakat funds. This trust and responsibility does not only report financial reports, the total collection and distribution of Zakat funds each year, to the government and the national Amil Zakat Agency, but also must be conveyed to the wider community as parties who have the potential to entrust their Zakat to Zakat institutions.

The public expects transparent and credible reporting. We can actually see this transparent standardization if we intend to find the financial reports of related Zakat institutions, also open the websites of Zakat institutions, to find out the Zakat distribution areas, and what activities are carried out by Zakat institutions (Zakat distribution activities).

Here, it appears that there is a gap where people have the convenience of giving Zakat anywhere and anytime, but it will be a bit difficult to get information related to reports on the distribution of Zakat funds. Moreover, the distribution of Zakat funds must essentially be grouped based on the area of beneficiaries, based on the agreement on the donations of Zakat, infaq and alms received, and various other types of distribution program specifications. Example; for mosque building programs, scholarships, $d a^{\prime}$ wah to prevent the Christianization of poor Muslim communities, business capital assistance for the poor, as well as community economic empowerment programs.

\subsection{Community Response to Information Technology-based on Zakat Services}

Previous research related to the behavior of paying Zakat by the community in general shows several determinants. Someone will pay Zakat through official institutions because of their respective intentions to adopt behavior. With this intention, the potential for the community to take action is even greater. Another factor that has great determination on the implementation of behavior is the ability of each individual to the existing environmental conditions.

Currently paying Zakat through Zakat institutions can be done through various ways, such as bank transfers, through applications that work with Zakat institutions, through social crowd funding websites, or directly visiting the service offices of Zakat institutions. The factor of the community's ability to utilize the services provided is the second most influential factor in making people pay Zakat through Zakat institutions. This reaffirms the importance of technological factors in today's community services. 


\subsection{Block chain for Worldwide Zakat Management}

The current collection strategy can increase Zakat donations and bring Zakat institutions closer to the community. However, the online Zakat saving strategy has not been matched with accountability for managing Zakat funds and Zakat assets online as well. Thus, this study not only looks at the potential for cash Zakat collection as a source of productive Zakat management, but also develops Zakat management strategies in a more integrated manner, both from the collection side and from the publication side of Zakat management reports. Namely, the Zakat payment management model and Zakat distribution reporting management using the Block-Chain system (worldwide Zakat Block-Chain). The concept needs to be tested for its potential development in the community in the future, by looking at the public's response to the need for integrated Zakat management reporting and Zakat management through worldwide Zakat management through Block-Chain.

Block-Chain is a system of record that is documented and spread across many databases. This system is also known as a distributed ledger. The Block-Chain system maintains the validity of existing transactions, and the movement of digital money will be clearly recorded and easy to trace. This decentralized transaction documentation minimizes changes in data unilaterally, and prevents cybercrime like hacks. Because transactions that have been recorded / created cannot be changed or deleted (are immutable) [9].

Block-Chain technology has been used for payment traffic transactions, because the costs are cheaper and faster in terms of time. It also makes stock trading easier because it is more accurate and the settlement process is faster. Block-Chain can also facilitate business transactions such as authorization and verification of documents, also make it easier to analyze consumer data and measure the level of consumer loyalty based on the frequency of transactions made. The auditing process and transaction tracing will also be easier to do, especially by the government, to eradicate fraudulent transactions such as corruption, bribery, and others [1].

\section{a) Block-Chain in Indonesia}

The Indonesian government's support for the Block-Chain system was conveyed by the Minister of Communication and Information, as long as it did not violate state principles, as there is virtual currency such as bitcoin which cannot be recognized in Indonesia. However, the government supports the use of block chain to improve the performance of existing businesses in Indonesia, such as for service systems from financial institutions such as banking. The Block-Chain system can provide transaction transparency, and can also be adapted to financial institutions such as banks in Indonesia, making it easier for banks to be able to track when, where, from where, and how much money is moving from one bank to another [9].

\section{b) Block-Chain Technology for Digital Zakat Management}

In the previous sub-chapter, the factors that can influence public acceptance of a technology have been explained, namely from the acceptance or perception of its usefulness 
and the perception of the ease of using the technology. Block-Chain is a technology that is the main topic in the technology acceptance model in this Zakat research. However, Block-Chain as a digital Zakat management system has not been implemented so that this research examines the opportunities and perceptions (acceptance) of the community with a more modern and comprehensive Zakat management namely the Block-Chain system.

Thus, although in general this research refers to a technology acceptance model with Block-Chain, where the influencing factors are the perception of use or usefulness and the perception of ease of using the system, this study includes several advantages of Block-Chain such as good security from cybercrime, fraud, fraud, manipulation, or others. As well as the efficiency that can be provided by implementing Block-Chain compared to existing digital technology. This research ends with the public's intention to tithe online using the worldwide Zakat by Block-Chain system.

\section{Objective and Research Method}

The aim of the study is to explore and investigate in more detail the implementation of Block-Chain technology to support Zakat management in Indonesia, Besides that, the study also to answer to what extend ICT will support people in paying Zakat, and also to what extend block-chain that will be designed in this study will beneficial to zakat institutions. In the early stages of the developed model, it is necessary to analyze the factors involved.

This research is a mixed method research, the data used in the study are secondary data and primary data extracted from several sources. The data collection technique uses triangulation (a combination of observation, interviews and documentation study). Respondents are people who have insight related to Zakat, and become Islamic economic activists, and academician as well. The respondents is divided three categories; Academicians, Islamic Finance Activists, Zakat Payer, and Scholars. Besides that, we distributed to six province; central java: 40 Respondents, West Java; 20 respondents, East Java: 20, Jakarta:20, Aceh as represent Sumatra: 40, Banjarmasin (as represent Kalimantan): 20; Makasar (as represent Sulawesi and Other) 30, Other Islands on East part of Indonesia: 10, so in total 200 respondents. We used by email, google form, bitly, WA group of Islamic Association. Sample method used area, stratified, purposive sampling. We have distributed 225 questionnaires but no all are deal with the requirements.

The respondents criteria who are Master graduated, and already go hajj, Besides that, $f$ respondents who have paid Zakat for more than 5 years. All the applied criteria to make sure that the respondents have good understanding regarding the implementation of Zakat. All the respondents to fill-up the questionnaires in order we can fulfill the kind of research namely analytic descriptive research which have aims to describe the factors increasing people's interest in in what technology to support Zakat management i.e. public acceptance on block chain concept to backup Zakat management.

\section{Result and Discussion}

In this section we will discuss about The Role ICT to Support Zakat Management, The Study on Using Block-Chain to Support Zakat Management and Block-Chain Model Based for Zakat Management Model. After that, we will discuss the Benefits of Using the Block- 
Chain System, later on, also discuss related the Use of Block-Chain from Technology Acceptance Model (TAM) Analysis, last but least, also the using Block-Chain Model in Zakat Management from Technology Acceptance Model (TAM) View.

\subsection{The Role ICT to Support Zakat Management}

The following is a summary of the outer loading from the process data in this research related people preferences in supporting Zakat management based on ICT.

Table 2. Analysis of Factors Affecting Community Behavior to Pay Zakat through Zakat Institutions Using ICT

\begin{tabular}{lccc}
\hline Indicators & Outer Loading & Significant & Rank \\
\hline Intention to use & 0.958 & Significant & 1 \\
\hline Intention to Recommend & 0.947 & Significant & 2 \\
\hline Intention to support & 0.943 & Significant & 3 \\
\hline Easy to Use & 0.924 & Significant & 4 \\
\hline Perceived Value & 0.907 & Significant & 5 \\
\hline Efficient Way & 0.902 & Significant & 6 \\
\hline
\end{tabular}

Source: The Process Data

Based on these data, people support Zakat management by using ICT are: people will increase intention to use the system is most importatnt factor, then followed by intention people to recommend others, intention to support this agenda is third rank, and people feel easy to use and perceived value are number five and six. Last but not least people consider Zakat management using ICT is efficient way.

\subsection{The Study on Using Block-Chain to Support Zakat Management}

The study related on the using Block-Chain in term of supporting Zakat management we involve four variables namely, Credibility, Accountability, Transparency, and Trust. We collected people opinion in term of the benefit for Zakat institution by using Block-Chain technology in Indonesia. We then derived sixteen indicators by P1 to P16 which is describing the construct of questionnaires. The result will summarized in the following Table.

Table 3. The Benefit of Zakat Institutions by Using Block-Chain ( Respondent's View)

\begin{tabular}{lclccc}
\hline Variable & Code & Questions Construct & Mean & Stdev & AVERAGE \\
\hline CREDIBILITY & P1 & Contact the OPZ & 5.93 & 1.74716 & 5.92 \\
& P2 & Pay Zakat regularly even though not through & 5.91 & 1.8880 & \\
ACCOUNTABILITY & & & & \\
& OPZ & Benefits (for Muslims) & 5.80 & 1.2728 & 5.80 \\
& P4 & Practicality & 5.75 & 1.3623 & \\
& P5 & Happy / pleasant feeling & 5.85 & 1.4806 & \\
& P6 & Possibility to do (because of its simplicity) & 5.70 & 1.292 & \\
TRANSPARENCY & P7 & Level of Importance & 5.90 & 1.4452 & \multirow{2}{*}{5.40} \\
& P8 & Independence of personal will & 5.55 & 1.6 & \\
& P9 & Belief in the capacity or ability of a certain & 5.45 & 1.346 & \\
& individual to behave & & & \\
& P10 & Ability to take advantage of facilities for & 5.70 & 1.301 & \\
& behavior & & & \\
& P11 & Ability to use information facilities & 5.30 & 1.266 & \\
\hline
\end{tabular}




\begin{tabular}{|c|c|c|c|c|c|}
\hline Variable & Code & Questions Construct & Mean & Stdev & AVERAGE \\
\hline \multirow[t]{5}{*}{ TRUST } & P12 & $\begin{array}{l}\text { The Zakat Management Organization (OPZ) } \\
\text { is open in the process of collecting and } \\
\text { distributing Zakat, Infaq, Alms (ZIS) funds. }\end{array}$ & 5.15 & 1.305 & 5.25 \\
\hline & P13 & $\begin{array}{l}\text { OPZ has a good and broad understanding of } \\
\text { ZIS (Zakat, Infaq Alms). }\end{array}$ & 5.25 & 1.173 & \\
\hline & P14 & $\begin{array}{l}\text { OPZ is able to convey well about ZIS (Zakat, } \\
\text { Infaq, Alms) to Muzakki. }\end{array}$ & 5.35 & 1.325 & \\
\hline & P15 & $\begin{array}{l}\text { OPZ publish reports of receipt and } \\
\text { distribution of ZIS funds. }\end{array}$ & 5.10 & 1.463 & \\
\hline & P16 & $\begin{array}{l}\text { OPZ distributes ZIS funds to eligible people } \\
\text { (right on target). }\end{array}$ & 5.25 & 1.462 & \\
\hline
\end{tabular}

Source : Data Analysis

This study uses indicate that if the Zakat institutions using block chain technology will increase the value of institution in terms of: first, creditability of the Zakat institutions. Second, will increase accountability so people want to pay Zakat, thirdly, transference, it will encourage people increase the belief to the Zakat institution. Last but not least, trust, it will increase people trust to the Zakat institutions. Therefore the using sophisticated technology i.e. block-chain is needed. The result also revealed that, results that credibility is the most factors, and followed by accountability, transparency, and trust.

Accountability and trust factor emphasizes that the existence of a professional Zakat institution can make it easier to pay Zakat, its distribution is more targeted, more practical. Even so, amil Zakat institutions still have to pay attention to the professionalism of Zakat institutions, there must be periodic reports, as well as being effective, accountable, and in accordance with sharia and in accordance with state regulations. Principles of usefulness and practicality that are dominant make the next indicator construct refer to the concept of the Technology Acceptance Model (TAM). This also strengthens the potential acceptance of a technology-based Zakat management model.

Credibility will be able for individuals to take advantage of technology is due to its simplicity, socialization of technology use, and creating transparency in distribution to society. The use of technology in these institutions can be increased by maintaining public trust in the institution. Moreover, transparency will be maintaining the professionalism of the institution, the mandate/distribution on target, reports that are open and periodically involved, involving muzakki in several activities of the amil Zakat institution, transparent in financial reports and pentasyarufah activities, becoming an independent institution, and there is no political element/affiliation with the government/certain party. The average value of the distribution factor and high professionalism, directs a model that can realize this accountability method.

The amil Zakat institution must also maintain regular reports to muzakki, accountable and transparent reports, openness of management information in the mass media, socialization, transparency, and managed productive programs, as well as openness and quality empowerment programs. By publishing a large and widespread coverage of beneficiaries, it is believed to increase public trust in Zakat institutions [13] [15]. Because the capacity of Zakat institutions is considered to be able to distribute Zakat funds optimally even to areas with minimal muzakki (not many rich Muslim communities).

\subsection{Block-Chain Model Based for Zakat Management Model}

Based on the results of the discussion in the previous sub-chapter, this study intends to compile a comprehensive picture of the use of Block-Chain for Zakat management. Namely 
Zakat management using Block-Chain which can present the design of the service for receiving / collecting Zakat funds, accompanied by reporting on the use and distribution of Zakat funds, in the same system. The scheme being carried is presented in Figure 1.

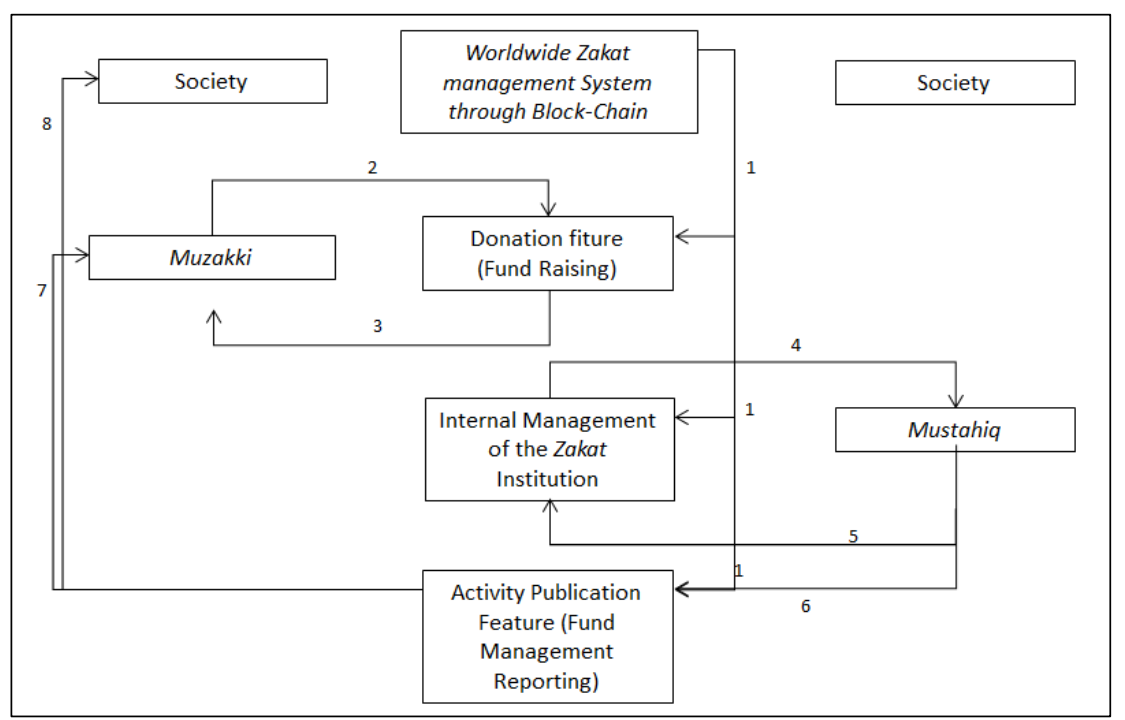

Discriptions:

Fig. 1. Block-Chain-based Zakat Management System Modeling

a) Emphasize the Zakat management system that is integrated in one system, namely the management of Zakat fund collection, internal, and reporting on the management and distribution of Zakat funds.

b) In this system Muzakki can directly make donations or Zakat payments. Transactions will be recorded in the database according to the muzakki identity, and the total additional donations will be visible to the general public in real time. In this donation feature, Zakat institution programs can also be displayed, so that muzakki or donors can donate based on the programs they support.

c) Muzakki or donors will automatically receive proof of donation. Donations for Zakat can be attached for tax reporting purposes. This is in accordance with the Indonesian government policy where Zakat payments at official amil Zakat institutions can be reported for deduction of PKP (taxable income). Muzakki can also see a recap of donations / contributions that have been made so far, as long as transactions are made through the system.

d) Zakat funds collected will be managed by Zakat institutions, then distributed to the appropriate mustahiq. If muzakki or donors donate to a particular program, it will be distributed to the program in question. This can maintain the conformity of the contract, and increase the transparency of the trustworthy Zakat institutions.

e) Feedback on the distribution of Zakat funds. In this flow, the feedback obtained can be in the form of a report on the distribution of funds, its impact on mustahiq, and a progress report on mustahiq's condition at times after assistance. Mustahiq follow-up is important in an effort to achieve the goal of converting people with mustahiq status into muzakki, especially if the program provided is in the form of economic empowerment assistance which also requires long-term business assistance. 
f) The resulting feedback is managed by Zakat institutions to produce reports that can be published to the public, especially muzakki. The report has a format that can be understood and educates the public that a program can be said to be successful if it meets certain standards. With standard procedures for distributing Zakat funds and implementing programs that are clear and known to the public, it can increase the credibility and perception of the institution's capability in the eyes of the community.

g) and 8. The community and Muzakki received reports on the distribution of funds along with ongoing actions (follow-up) in an effort to foster mustahiqs so that they can live more independently (not become mustahiqs) anymore. In this flow, the community will increasingly understand that building humans is not just providing assistance once then there is no follow-up step, but building people needs a process of mentoring and coaching so that they can finally convert mustahiq into muzakki. In accordance with the nature of Zakat.

\subsection{Benefits of Using the Block-Chain System}

Some of the benefits that we can get by utilizing this technology include the following [6]: Firstly, Wider access to finance: The presence of Block-Chain makes access wider because it is able to reach all transactions without being restricted and supervised by third parties. Access speed can also be increased because you use your own server, not a centralized server. Secondly, Business runs become more efficient: Block-Chain can serve financial transactions anytime and anywhere without any time and space restrictions. This is especially efficient for businesses that have partners in other parts of the world. Thirdly, Cheap: One of the advantages of using other Block-Chain technology is that it is cheaper than conventional banking services. Fourthly, Safe: Every transaction that occurs on the Block-Chain can be validated at that time. Existing data can be read by several databases. In addition, the application of a digital signature can also be done to confirm the identity of a person or user who has an account on the Block-Chain. The signature can also arrange for permissions to provide data and access history [6].

\subsection{The Use of Block-Chain from Technology Acceptance Model (TAM) Analysis}

The Technology Acceptance Model is a type of theory that uses a behavioral theory approach to study the process of adoption and adaptation of a person to information technology. The concept of the TAM model predicts how users accept and use the new technology. Namely by observing psychological conditions, such as beliefs, attitudes, interests, and user behavior relationships [11]. The basic purpose of TAM is to provide an explanation of what factors determine the acceptance of technology that are able to explain user behavior [3]. Thus using TAM will be able to explain how the Zakat management system procurement project can be accepted by the community at large.

Various studies conducted by researchers have tried to modify TAM by adding new variables to it. Generally acceptance of technology is shown from an opinion on the convenience and usefulness of the new technology [11]. Then TAM is modified by adding the constructs of compatibility, cognitive absorption, and pleasure [3], experience in utilizing technology, self-efficacy, perceived risk and social influence [11]. On the other hand, perceived acceptance must also consider the emotions that are felt in the short and long term, so that users will tend to take advantage of this technology in the long term [1]. In terms of appearance, technology must also be presented in a visual form that is attractive, easy to 
understand, and entertaining (increases feelings of pleasure) [4]. That means it must adjust the system presentation technique designed in accordance with the segmentation or characteristics of today's society.

Digital technology, especially if the technology is related to money transactions, must have a sophisticated and guaranteed security system [1]. Design and security are stimuli that represent system capabilities and features, while ease of use and perceived usefulness are organisms that represent motivation to use systems that lead to consumer responses to using the system [1]. The acceptance factor of a technology can come from the user (intrinsic factor) and the system itself (extrinsic factor) [7]. Intrinsic factor means that it emerges from within the individual user, while extrinsic factor means that it is due to environmental factors that encourage users to use information systems [11]. From users can be in the form of cognitive aspects, individual character, personality, individual concerns about the impact of technology. Meanwhile, the system can be in the form of a computer network, the state of the computer, complexity, trust, self-efficacy, social factors, service assurance, internet connection quality, and so on [11].

The main external factors that usually manifest are social factors, cultural factors and political factors [16]. Social factors include language, skills, and conditions for facilitation. Political factors are mainly the impact of technology use in politics and political crises. The attitude to use relates to the user's evaluation of the desire to use certain information system applications. Behavioral intention is a measure of a person's likelihood of using an application [16]. In general, if it turns out that after a study it turns out that the convenience factor for the information system is known to be no convenience, then the usefulness factor will also be invisible. Logically, how can it be useful for users if the information system is difficult to use or not easy to use [11].

Perceptions of usefulness and ease of use will affect attitudes towards the use of information systems and then affect the intensity of use. After that it will affect the actual use of the system. However, this study intends to examine the potential for public acceptance of a more complete openness model of Zakat management, so that it does not yet have actual activities. So that the final variable is more directed at increasing the intention to utilize cash Zakat facilities online [11]. The using of Block-Chain model will beneficial in two ways: Firstly: Perceived of Usefulness Perception. In Davis (1989) states that "the degree to which a person believes that using a particular system would enhance his or her job performance." This means that users believe that using the library information system will improve its performance. This illustrates the benefits of the system from its users in relation to various aspects. So in this usefulness perception forms a belief for decision making whether to use an information system or not. The assumption is that if the user believes that the system is useful, then of course he will use it, but on the other hand, if he does not believe that it is useful, the answer will definitely not use it [11].

Secondly: Increasing Performance. Several indicators that reflect the perceived usefulness include; accelerating work, increasing performance, increasing productivity, effectiveness, making work easier, and also useful [3] [11]. The final objective of this research is to form a comprehensive Zakat management system with the help of the Block-Chain system. Thus the perception of the benefits that can only be felt at this time is the existing Zakat service facilities; online Zakat collection services either through transfers, marketplaces, merchants, or other online systems. Several indicators will be adjusted to the context of the study such as; up to date compilation reporting, neat and valid recording, fast transaction confirmation, fast / efficient transactions. Some of these things are thought to be able to make people willing to give Zakat online. 
Thirdly: Perceived on Easiness of Use. It is stated that "ease" means "freedom from difficulty or great effort". Furthermore, "ease to use perceived" is defined as "the degree to which a person believes that using a particular system would be free of effort" [3]. If applied to a library information system, it means that the user believes that the library information system is easy to use so that it does not require hard effort and will be free from difficulties. This includes the ease of use of the information system in accordance with the wishes of its users. Davis's research results show that perceived convenience can explain users' reasons for using the system and can explain that the new system can be accepted by users [11]. Details things that are included in the perception of ease of use such as; easy to learn (easy to learn), controllable (controllable), clear and understandable, flexible, easy to be skilled / proficient, and easy to use [11].

\subsection{Using Block-Chain Model in Zakat Management from Technology Acceptance Model (TAM) View}

The following is a roadmap of a thought formula to test the potential acceptance of a block chain-based Zakat management system in Indonesia.

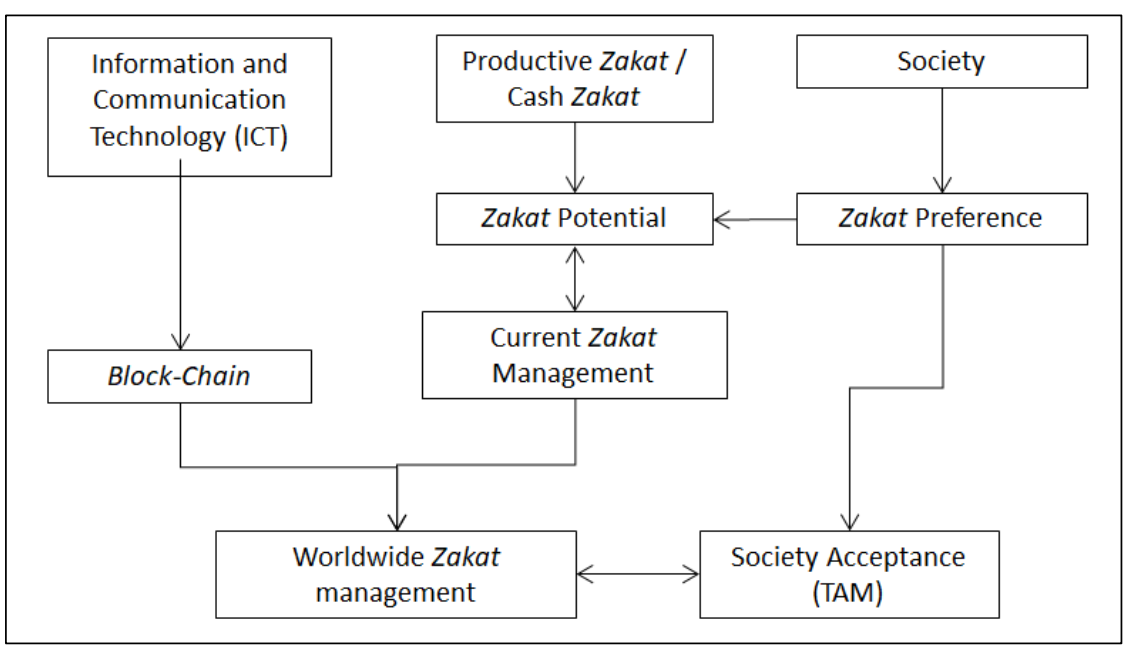

Fig. 2. Technology Acceptance Model Framework: Worldwide Zakat through Block-Chain System

Block-Chain makes use of consensus, the condition that is reached when all the participants in the network agree on the validity of a transaction by noting that what the computer records in big data matches each other. Block-Chain will be publicly visible (open source) like a bank ledger that records all customer transactions. Because it can be seen in general, the possibility of fraud can be minimized. The technology can also be used for other contract-based agreements, and works in such a way that no single entity is controlling the transactions - because everyone controls every transaction. And with this database system technology, all user transactions can be recorded in blocks which are protected with complex passwords. 


\section{Conclusion}

The study on Zakat management by using Block-Chain technology can be concluded as follows:

a) The use of ICT in Zakat management will increase people support for paying Zakat. The use of ICT in Zakat management will increase people's intention to use the system and it is the most important factor, then followed by intention of people to recommend others, intention to support this agenda is third rank, and people feel easy to use and perceived value are number five and six. Last but not least people consider Zakat management by using ICT is an efficient way.

b) Zakat institutions using block-chain technology will increase the value of institution in terms of: first, credibility of the Zakat institutions. Second, will increase accountability so people want to pay Zakat, thirdly, transparency, it will encourage people and increase their belief to the Zakat institution. Last but not least, trust, it will increase people trust to the Zakat institutions. Therefore, using sophisticated technology i.e. Block-Chain is needed. The result also revealed that credibility is the most factors, and followed by accountability, transparency, and trust.

c) The Block-Chain Model in Zakat management that has been developed will make close relationship between Zakat payer ( muzakki), the benefeceries of Zakat ( mustahiq) and Zakat institutions, and also society will be easy to monitor the use of Zakat. Besides, the benefit of using Block-Chain in Zakat make wider (arround the world) access to finance globally, Business runs become more efficient, Cheap, and Safe.

d) In term of TAM (Technology Acceptance Model) the using of Block-Chain in Zakat management will facilitate in three ways, namely; Perceived of Usefulness Perception, Increasing Performance and Perceived on Easiness of Use.

\section{References}

[1] Medina, Aulia. 2019. 5 Kegunaan Teknologi Blockchain Dalam Layanan Keuangan. https:/coinvestasi.com/belajar/5-kegunaan-teknologi-blockchain/

[2] Nasution, M.E. (2006). Zakat dan wakaf sebagai Pilar dalam Sistem Perekonomian Nasional.

[3] Nicholson, W.(1989). Microeconomics Theory: Basic Principles and Extensions. (Teori Ekonomi MikroI, alih bahasa Deliarnov). Jakarta: CV. Rajawali.

[4] Sabit, M. (2006). Innovative modes of financing: The development of zakat. Kuala Lumpur.

[5] Sabit, M.T. (2006). Innovative modes of financing the development of Zakat properties in Malaysia. Kuala Lumpur.

[6] Safitri, Dita. 2018. Manfaat Yang Bisa Didapatkan Dari Teknologi Blockchain Dan Mata Uang Virtual. https://www.duniafintech.com/manfaat-yang-bisa-didapatkan-dariteknologi-blockchain-dan-mata-uang-virtual/. 18 Januari 2018

[7] Setiadi, N.J. (2013). Perilaku Konsumen. Jakarta: Kencana Prenada Media Group.

[8] Wigati, S.(2011, June). Perilaku Konsumen Dalam Perspektif Ekonomi Islam. Maliyah, p. Vo.01 No.01.

[9] Yuliani, Ayu. 2018. Beda Blockchain dengan Bitcoin. https://www.kominfo.go.id/content/detail/11966/beda-blockchain-denganbitcoin/0/sorotan_media 
[10] Amilahaq, F., \& Ghoniyah, N. (2019). COMPLIANCE BEHAVIOR MODEL OF PAYING ZAKAT ON INCOME THROUGH ZAKAT MANAGEMENT. SHARE: Jurnal Ekonomi Dan Keuangan Islam, 8(1), 114-141. https://doi.org/10.22373/share.v8i1.3655

[11] Azman, F. M. N., \& Bidin, Z. (2015). Factors Influencing Zakat Compliance Behavior on Saving. International Journal of Business and Social Research, 05(01), 118-128.

[12] BAZNAS. (2017). Outlook Zakat Indonesia 2017. Jakarta. Retrieved from https://www.puskasbaznas.com/images/outlook/OUTLOOK_ZAKAT_2017_PUSKAS BAZNAS.pdf

[13] Bidin, Z., Deraman, M. J., \& Othman, M. Z. (2017). Individual Determinats of Zakat Compliance Intention on Saving. In A. H. M. Noor, R. Nordin, M. S. A. Rasool, D. Sharif, N. Rabu, \& F. Johari (Eds.), 5th South East Asia International Islamic Philantrophy Conference 2017 (pp. 365-376). Melaka, Malaysia: Center for Islamic Philanthropy and Social Finance (CIPSF). Retrieved from http://www.cipsf.my/seaiipc Center of Strategic Studies - [14] The National Board of Zakat. (2019). Indonesia Zakat Outlook 2019. Jakarta. Retrieved from https://drive.google.com/file/d/1tN1FdA0UYJmrVV-QHWNi2NesfHD 9HET/view

[15] Fahrurrozi. (2014). Fundraising Berbasis ZIS: Strategi Inkonvensional Mendanai Pendidikan Islam.

[16] Firdaus, M., Beik, I. S., Irawan, T., \& Juanda, B. (2012). Economic Estimation and Determinations of Zakat Potential in Indonesia. IRTI Working Paper Series, WP 143307(August), 1-74. Retrieved from http://www.isdb.org

[17] Hafidhuddin, D. (2006). Zakat dalam Perekonomian Modern. (I. Kelana, Ed.). Jakarta: Gema Insani.

[18] Jumaizi, J., \& Wijaya, Z. A. (2011). Good Governance Badan Amil Zakat, Infak , dan Sedekah Dan Dampaknya Terhadap Keputusan dan Loyalitas Muzaki | unaki | Majalah Ilmiah INFORMATIKA. Retrieved from http://www.unaki.ac.id/ejournal/index.php/majalah-ilmiahinformatika/article/view/51/84

[19] Kashif, M., Faisal Jamal, K., \& Abdur Rehman, M. (2018). The dynamics of Zakat donation experience among Muslims: a phenomenological inquiry. Journal of Islamic Accounting and Business Research, 9(1), 45-58. https://doi.org/10.1108/JIABR-012016-0006

[20] Kurnia, H. H., \& Hidayat, H. A. L. (2008). Panduan Pintar Zakat. (D. N. M. A. Nuraeni, Ed.). 2008: QultumMedia.

[21] Mufraini, M. A. (2008). Akuntansi dan Manajemen Zakat (1st ed.). Jakarta: Kencana Publisher.

[22] Mukhlis, A., \& Beik, I. S. (2013). Analysis of Factors Affecting Compliance Level of Paying Zakat: A Case Study in Bogor Regency. Jurnal Al-Muzara'ah, I(1), 83-106.

[23] Owoyemi, M. Y. (2020). Zakat management. Journal of Islamic Accounting and Business Research, 11(2), 498-510. https://doi.org/10.1108/JIABR-07-2017-0097

[24] Sartika, M. (2008). Pengaruh Pendayagunaan Zakat Produktif terhadap Pemberdayaan Mustahiq pada LAZ Yayasan Solo Peduli Surakarta. La_Riba, Jurnal Ekonomi Islam, II(1), 75-89.

[25] Tajuddin, T. S., Azman, A. S., \& Shamsuddin, N. (2015). COMPLIANCE BEHAVIOUR OF ZAKAT ON SALARY INCOME AMONG MUSLIM YOUTH IN KLANG VALLEY. In International Conference on Social Science Research, ICSSR (pp. 656-664). Kuala Lumpur, Malaysia. Retrieved from http://worldconferences.net 
[26] Tajuddin, T. S., Azman, A. S., \& Shamsuddin, N. (2016). ZAKĀH COMPLIANCE BEHAVIOUR ON INCOME AMONG MUSLIM YOUTH IN KLANG VALLEY | Jurnal Syariah. Shariah Journal, 24, 445-464. Retrieved from https://ejournal.um.edu.my/index.php/JS/article/view/4356

[27] Yunus, M. (2016). Analisis Pengaruh Kepercayaan, Religiusitas, dan Kontribusi terhadap Minat Pedagang Mengeluarkan Zakat di Baitul Mal (Studi Kasus pada Pedagang Pasar Los Lhokseumawe). At-Tawassuth, 1(1), 95-124. 